\title{
A MULTIDIMENSIONAL DISCRETE HILBERT-TYPE INEQUALITY
}

\section{BICHENG YANG AND QIANG CHEN}

Abstract. In this paper, by using the way of weight coefficients and technique of real analysis, a multidimensional discrete Hilbert-type inequality with parameters and a best possible constant factor is given. The equivalent form, the operator expressions with the norm are also considered.

Mathematics subject classification (2010): 26D15, 47A07.

Keywords and phrases: Hilbert-type inequality, weight coefficient, equivalent form, operator, norm.

\section{REFERENCES}

[1] G. H. Hardy, J. E. Littlewood, G. Pólya, Inequalities, Cambridge University Press, Cambridge (1934).

[2] D. S. Mitrinović, J. E. PeČArić, A. M. FinK, Inequalities involving functions and their integrals and derivatives, Kluwer Acaremic Publishers, Boston (1991).

[3] B. C. YANG, Hilbert-type integral inequalities, Bentham Science Publishers Ltd., Sharjah (2009).

[4] B. C. YANG, Discrete Hilbert-type inequalities, Bentham Science Publishers Ltd., Sharjah (2011).

[5] B. C. YANG, The norm of operator and Hilbert-type inequalities, Science Press, Beijin, 2009 (China).

[6] B. C. YANG, Two types of multiple half-discrete Hilbert-type inequalities, Lambert Academic Publishing (2012).

[7] B. C. YANG, On Hilbert's integral inequality, Journal of Mathematical Analysis and Applications, 220, 778-785 (1998).

[8] B. C. Yang, I Brnetić, M. Krnić, J. E. PeČArić, Generalization of Hilbert and Hardy-Hilbert integral inequalities, Math. Ineq. and Appl., 8 (2), 259-272 (2005).

[9] M. KRnić, J. E. PeČArić, Hilbert's inequalities and their reverses, Publ. Math. Debrecen, 67 (3-4), 315-331 (2005).

[10] B. C. YANG, TH. M. RAssias, On the way of weight coefficient and research for Hilbert-type inequalities, Math. Ineq. Appl., 6 (4), 625-658 (2003).

[11] B. C. YANG, TH. M. RASSIAS, On a Hilbert-type integral inequality in the subinterval and its operator expression, Banach J. Math. Anal., 4 (2), 100-110 (2010).

[12] L. AZAR, On some extensions of Hardy-Hilbert's inequality and Applications, Journal of Inequalities and Applications, 2009, no. 546829.

[13] B. Arpad, O. Choonghong, Best constant for certain multilinear integral operator, Journal of Inequalities and Applications, 2006, no. 28582.

[14] J. C. Kuang, L. Debnath, On Hilbert's type inequalities on the weighted Orlicz spaces, pacific J. Appl. Math., 1 (1), 95-103 (2007).

[15] W. Y. ZhONG, The Hilbert-type integral inequality with a homogeneous kernel of Lambda-degree, Journal of Inequalities and Applications, 2008, no. 917392.

[16] Y. Hong, On Hardy-Hilbert integral inequalities with some parameters, J. Ineq. in Pure \& Applied Math., 6 (4), Art. 92, 1-10 (2005).

[17] W. Y. ZhONG, B. C. YANG, On multiple Hardy-Hilbert's integral inequality with kernel, Journal of Inequalities and Applications, Vol. 2007, Art. ID 27962, 17 pages, doi: 10.1155/2007/27.

[18] B. C. YANG, M. KRniĆ, On the Norm of a Mult-dimensional Hilbert-type Operator, Sarajevo Journal of Mathematics, 7 (20), 223-243 (2011).

[19] M. KRnić, J. E. PeČARIĆ, P. Vuković, On some higher-dimensional Hilbert's and Hardy-Hilbert's type integral inequalities with parameters, Math. Inequal. Appl., 11, 701-716 (2008). 
[20] M. KRnić, P. Vuković, On a multidimensional version of the Hilbert-type inequality, Analysis Mathematica, 38, 291-303 (2012).

[21] Y. J. LI, B. HE, On inequalities of Hilbert's type, Bulletin of the Australian Mathematical Society, 76 (1), 1-13 (2007).

[22] B. C. YANG, A mixed Hilbert-type inequality with a best constant factor, International Journal of Pure and Applied Mathematcs, 20 (3), 319-328 (2005).

[23] B. C. YANG, A half-discrete Hilbert-type inequality, Journal of Guangdong University of Education, 31 (3), 1-7 (2011).

[24] W. Y. ZHONG, A mixed Hilbert-type inequality and its equivalent forms, Journal of Guangdong University of Education, 31 (5), 18-22 (2011).

[25] W. Y. ZHONG, A half discrete Hilbert-type inequality and its equivalent forms, Journal of Guangdong University of Education, 32 (5), 8-12 (2012).

[26] J. H. ZhONG, B. C. YANG, On an extension of a more accurate Hilbert-type inequality, Journal of Zhejiang University (Science Edition), 35 (2), 121-124 (2008).

[27] J. H. ZHONG, Two classes of half-discrete reverse Hilbert-type inequalities with a non-homogeneous kernel, Journal of Guangdong University of Education, 32 (5), 11-20 (2012).

[28] W. Y. ZhONG, B. C. YANG, A best extension of Hilbert inequality involving several parameters, Journal of Jinan University (Natural Science), 28 (1), 20-23 (2007).

[29] W. Y. ZHONG, B. C. YANG, A reverse Hilbert's type integral inequality with some parameters and the equivalent forms, Pure and Applied Mathematics, 24 (2), 401-407 (2008).

[30] B. C. YANG, Q. CHEN, A half-discrete Hilbert-type inequality with a homogeneous kernel and an extension, Journal of Inequalities and Applications, 124 (2011), doi:10.1186/1029-242X-2011-124.

[31] B. C. YANG, A half-discrete Hilbert-type inequality with a non-homogeneous kernel and two variables, Mediterranean Journal of Methematics, 2012, doi: 10.1007/s00009- 012- 0213-50 online first.

[32] B. C. YANG, Hilbert-type integral operators: norms and inequalities (In Chapter 42 of "Nonlinear nalysis, stability, approximation, and inequalities" (P. M. Paralos et al.)). Springer, New York, 771-859 (2012).

[33] J. C. KuAng, Applied inequalities, Shangdong Science Technic Press, Jinan, China (2004). 